\title{
Spatial and Seasonal Variation of Dissolved Nitrous Oxide in Wetland Groundwater
}

\author{
Xing Li ${ }^{1}$, Changyuan Tang ${ }^{1}$, Zhiwei Han ${ }^{1}$, Piao Jingqiu ${ }^{1}$, Cao Yingjie ${ }^{1} \&$ Zhang Chipeng ${ }^{1}$ \\ ${ }^{1}$ Graduate School of Horticulture, Chiba University, Matsudo, Japan \\ Correspondence: Changyuan Tang, Graduate School of Horticulture, Chiba University, 648 Matsudo, \\ Matsudo-shi, Japan. Tel: 81-47-308-1714. E-mail: tangchangyuan@gmail.com
}

Received: August 26, 2013 Accepted: November 12, 2013 Online Published: December 3, 2013

doi:10.5539/ep.v3n1p21 URL: http://dx.doi.org/10.5539/ep.v3n1p21

\begin{abstract}
Understanding the spatial and temporal pattern of dissolved nitrous oxide $\left(\mathrm{N}_{2} \mathrm{O}\right)$ in groundwater is essential to estimate the $\mathrm{N}_{2} \mathrm{O}$ emissions from groundwater to the unsaturated zone and to the atmosphere. In order to study the spatial distribution and seasonal change of dissolved $\mathrm{N}_{2} \mathrm{O}$ in wetland, a headwater wetland in Ichikawa, Chiba Prefecture, Japan, was chosen. Variations of nitrate $\left(\mathrm{NO}_{3}{ }^{-}\right)$, dissolved $\mathrm{N}_{2} \mathrm{O}$ and $\delta^{15} \mathrm{~N}^{-} \mathrm{NO}_{3}{ }^{-}$indicated that the dissolved $\mathrm{N}_{2} \mathrm{O}$ in the groundwater of study wetland consists of two parts, one from denitrification within the wetland, and another from nitrification at upland. Principal component analysis (PCA) was used to assess the shallow groundwater parameters in the wetland. And t-test was conducted to find statistically significant differences of the variables between the ASW and NS, warm season and cool season. The concentrations of dissolved $\mathrm{N}_{2} \mathrm{O}$ increased from the upland to the zone of adjacent area between slope and wetland (ASW) and then decreased at the zone near the stream (NS). In sight of dissolved $\mathrm{N}_{2} \mathrm{O}$ associated nitrogen migration, groundwater in the study area can be divided into three stages: upland as the stage 1, ASW as the stage 2, and NS as the stage 3. Higher temperature results in higher denitrification rate, lower dissolved oxygen (DO) and oxidation-redox potential (ORP), yielding higher concentration of $\mathrm{N}_{2} \mathrm{O}$ in the warm season. Therefore, the seasonal change of dissolved $\mathrm{N}_{2} \mathrm{O}$ in study wetland can be mainly interpreted by the variation of temperatures of groundwater.
\end{abstract}

Keywords: dissolved $\mathrm{N}_{2} \mathrm{O}$, spatial distribution, seasonal change, denitrification, stage

\section{Introduction}

Over the last few decades, much interest has been focused on specific natural systems, such as wetland (or riparian zone) which are vulnerable to improve water quality by physical, chemical and biological process that remove N from groundwater (García-García, Gómez, Vidal-Abarca, \& Suárez, 2009; Groffman, Gold, \& Simmons, 1992; Sabater et al., 2003). Wetlands offer an abundant organic C supply and dominated by inherently wet surface soil create anaerobic environment to consume nitrate via denitrification that is considered the most important reaction for nitrate removal in aquifer (Bastviken, Olsson, \& Tranvik, 2003; Burgin \& Hamilton, 2007; Whitmire \& Hamilton, 2005). Especially in the shallow ground water of riparian areas, redox conditions are often favorable for intense denitrification processes (Ross, 1995).

The trace gas $\mathrm{N}_{2} \mathrm{O}$ is an obligate intermediate product of biological denitrification. And it is known to contribute to global warming and the destruction of stratospheric ozone. A significant amount of $\mathrm{N}_{2} \mathrm{O}$ emissions originates denitrification (Mathieu et al., 2006). Emissions from aquifers are most likely to occur from shallow aquifers, where $\mathrm{N}_{2} \mathrm{O}$ can be quickly transferred through the unsaturated zone to the atmosphere by diffusion (Rice \& Rogers, 1993). $\mathrm{N}_{2} \mathrm{O}$ emission from wetland system has been estimated by numerous studies (Dhondt, Boeckx, Hofman, \& Van Cleemput, 2004; Groffman, Gold, \& Addy, 2000; Verhoeven, Arheimer, Yin, \& Hefting, 2006). Understanding the spatial and seasonal pattern of dissolved $\mathrm{N}_{2} \mathrm{O}$ is essential to assess the indirect emission of $\mathrm{N}_{2} \mathrm{O}$ from groundwater (Geistlinger, Jia, Eisermann, \& Florian Stange, 2010). Level of dissolved $\mathrm{N}_{2} \mathrm{O}$ in groundwater has been paid lots of attentions. For example, $\mathrm{N}_{2} \mathrm{O}$ concentration in groundwater was reported to exceed greatly those of atmospheric equilibration (with a mean value of $28.98 \mu \mathrm{g} \mathrm{L}^{-1}$ ) under aerobic condtion in Kanto district, Japan (Ueda, Ogura, \& Yoshinari, 1993), and the maximum up to 30000 times of that in the ambient air (Heincke \& Kaupenjohann, 1999). However, few studies estimated level of dissolved $\mathrm{N}_{2} \mathrm{O}$ in wetland groundwater. 
According literature review, study of spatial pattern of dissolved $\mathrm{N}_{2} \mathrm{O}$ has been focused on surface water, such as river, lake and ocean (Butler, Elkins, Thompson, \& Egan, 1989; Ferrón, Ortega, \& Forja, 2010; Hinshaw \& Dahlgren, 2013; Wang et al., 2009; Zhang, Zhang, Liu, Ren, \& Zhao, 2010). The pattern of seasonal and spatial of dissolved $\mathrm{N}_{2} \mathrm{O}$ is related to denitrification or nitrification depending on the environment in watershed. For example, the highest concentrations of dissolved $\mathrm{N}_{2} \mathrm{O}$ were observed in the riparian zone in May (warm season), when the nitrate $\left(\mathrm{NO}_{3}{ }^{-}\right)$and temperature were conducive for denitrification (Dividson, Stark, \& Firestone, 1990). However, Kim, Isenhart, Parkin, Schultz, and Loynachan (2009) found that dissolved $\mathrm{N}_{2} \mathrm{O}$ concentrations were with the highest value in cool season and the lowest value in warm season. Thus, the pattern of seasonal change of dissolved $\mathrm{N}_{2} \mathrm{O}$ in wetland is unclear. In addition, $\mathrm{N}_{2} \mathrm{O}$ also could product from nitrification (fertilizer and manure ammonium-nitrogen is oxidized to nitrate-nitrogen) in unsaturated zone. $\mathrm{N}_{2} \mathrm{O}$ could leach to groundwater at upland and discharge to wetland through the groundwater flow system (Mühlherr \& Hiscock, 1998; Spalding \& Parrott, 1994). However, few studies estimated the contribution of the $\mathrm{N}_{2} \mathrm{O}$ from nitrification at upland to dissolved $\mathrm{N}_{2} \mathrm{O}$ in wetland.

Therefore, the objectives of this study were 1) to identify the source of dissolved $\mathrm{N}_{2} \mathrm{O}$ and its evolution stages based on $\delta^{15} \mathrm{~N}_{-} \mathrm{NO}_{3}{ }^{-}, \mathrm{NO}_{3}{ }^{-}$and dissolved $\mathrm{N}_{2} \mathrm{O}$; and 2) to understand comprehensively the spatial distribution and seasonal change of dissolved $\mathrm{N}_{2} \mathrm{O}$ concentration in shallow groundwater of headwater wetland. As a matter of convenience, we define the groundwater are at stage 1 in upland where the dissolved $\mathrm{N}_{2} \mathrm{O}$ is produced from nitrification, stage 2 where more dissolved $\mathrm{N}_{2} \mathrm{O}$ is produced than consumed in denitrification in wetland, and stage 3 where the net of dissolved $\mathrm{N}_{2} \mathrm{O}$ decreases resulting from little available nitrate and its reduction to $\mathrm{N}_{2}$ as a proceed stage of stage 2 .

\section{Sites Description and Method}

\subsection{Site Description}

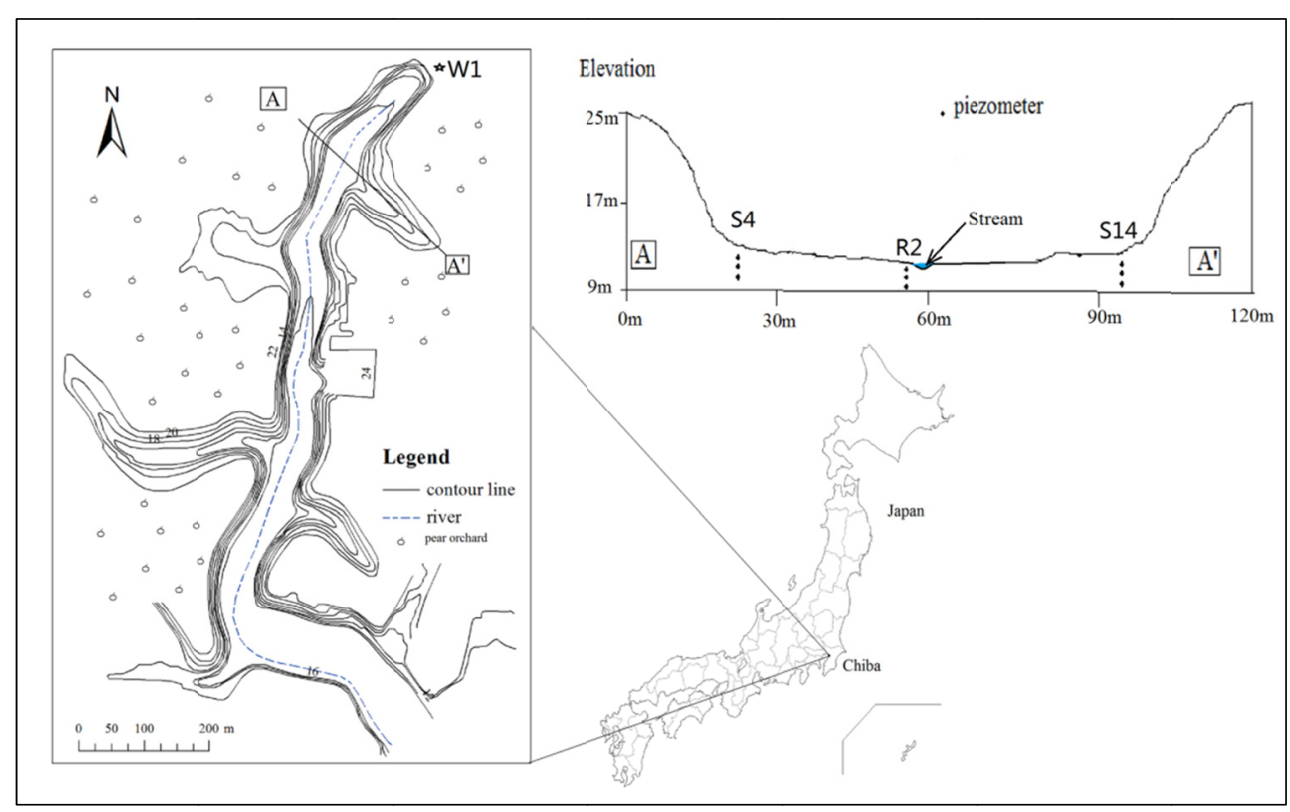

Figure 1. Study sites in Ichikawa, Japan. S4, R2 and S14 constitute transect A within the wetland and W1 is located in the upland site

The study area is a headwater wetland, located at Ichikawa City $\left(35.76^{\circ} \mathrm{N}, 139.97{ }^{\circ} \mathrm{E}\right)$, Chiba Prefecture, Japan (Figure 1). The wetland valley is U-shaped with an elevation of about $12 \mathrm{~m}$ above sea level. The wetland receives discharge (both groundwater and overland flow) from an adjancent upland (elevation 25-28 m) area mostly pear orchard vegetation. A stream flowing through the wetland valley is recharged by spring water and groundwater in the wetland. Previously, this wetland used to be paddy field and had been redeveloped to a wetland park. Average yearly flow of the stream from the study weland is about $6.70 \times 10^{5} \mathrm{~m}^{3} \mathrm{year}^{-1}$. Dominating vegetation in the wetland are Houttuynia, Calamus and Japanese pampas grass. The slope is close to the orchard edge and is decreasing towards the wetland. It acts as a transitional zone linking the upland and the experimental wetland. The slope is covered by Acer, Pinophyta and Bambuseae. The annual average precipitation is $1,316 \mathrm{~mm}$, with a 
maximum monthly precipitation of $226.5 \mathrm{~mm} \mathrm{month}^{-1}$ in May of study area. The annual average temperature is $15.6{ }^{\circ} \mathrm{C}$ with a highest temperature of $36.9^{\circ} \mathrm{C}$ in August and a lowest temperature of $-3.4{ }^{\circ} \mathrm{C}$ in January. The nitrogen load in pear orchard of the upland is estimated about $400 \mathrm{~kg} \mathrm{ha}^{-1}$ year ${ }^{-1}$ (Agriculture and Forestry Research Center of Chiba Prefecture, 2003). The area of pear orchard in Ichikawa city is 272 ha which account for $45 \%$ of agricultural land of Ichikawa city. The upland is covered by Kanto Loam about $4 \mathrm{~m}$ in thickness. It is underlain in a sequence by Joso clay layer and narita sand. That is a fine sand layer which is the major aquifer and the water table was about $17 \mathrm{~m}$ above sea level at upland all around the year. Within the wetland, the aquifer is a fine sand layer overlaid by cohesive soil and sandy clay with the water table depth $>11.6 \mathrm{~m}$ above sea level.

\subsection{Sampling Procedures and Measurements}

Field surveys were conducted in May, July, September and November in 2011, March and June in 2012. The study area is characterized by a temperate climate with warm season from June to September and cool season from November to May. Water samples were taken from well W1 at the upland and piezometers which were installed at S4, S14 and R2 with depths of $1 \mathrm{~m}, 2 \mathrm{~m}$ and $3 \mathrm{~m}$ in the wetland, for a total of 9 piezometers (Figure 1). S4 and S4 and S14 were at the sides of wetland and R2 was placed approximately $0.3 \mathrm{~m}$ on the west side of the stream. In order to get the fresh groundwater, we withdrew water from the piezometers and waited the fresh groundwater flowing in. In order to avoid the loss of dissolved gas during the sampling, a new sampler has been developed (Figure 2a). The sampler was inserted into the bottom of piezometer slowly with the outlet opened and the inlet closed. The inlet was opened by drawing the rope stopper to let the fresh groundwater flow in gently, make the vial $(35 \mathrm{ml})$ full and push out the air inside through tube with the three-way stopcock. After closing the three-way stopcock, the sampler was taken out from the piezometer and the vial was sealed with a rubber cap under the water in the sampler as soon as possible. $1 \mathrm{ml}$ sterilant (hibitane) was injected into the vial through the cap after water collection. Dissolved $\mathrm{N}_{2} \mathrm{O}-\mathrm{N}$ concentration was determined by headspace method. 10 $\mathrm{ml}$ pure $\mathrm{N}_{2}$ gas was injected into the vial to push out an equal volume of water from the vial. Vials were shaken for 1 minute and stored at $40{ }^{\circ} \mathrm{C}$ for $24 \mathrm{~h}$ to equilibrate. The gas samples were analyzed for target gas $\left(\mathrm{N}_{2} \mathrm{O}\right)$ by a gas chromatography (GC14B, Shimazu) equipped with an electron capture detector operated at $280{ }^{\circ} \mathrm{C}$, injector at $100^{\circ} \mathrm{C}$ and column at $700{ }^{\circ} \mathrm{C}$.
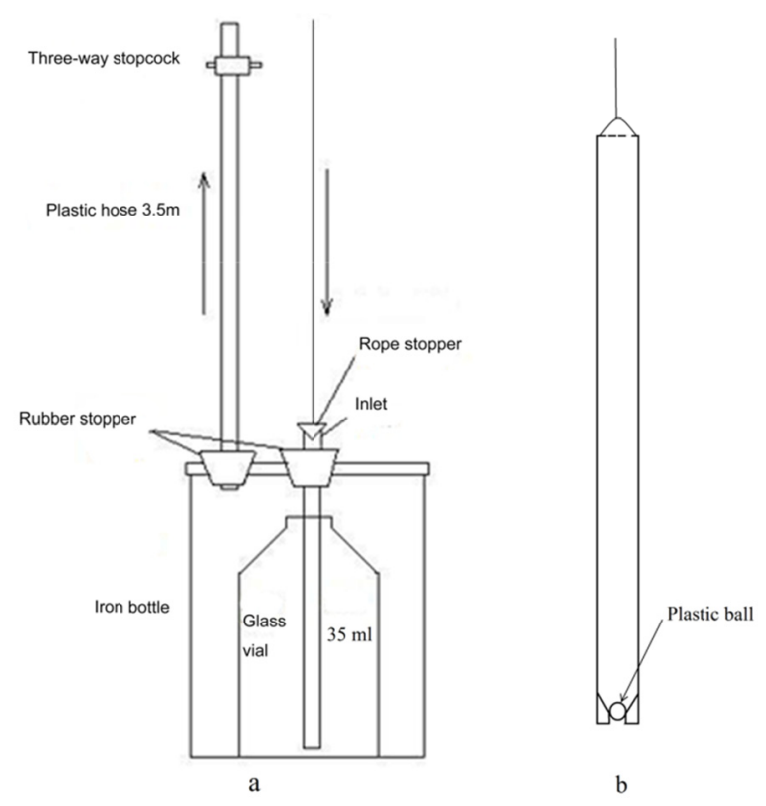

Figure 2. The schematic diagram of sampler for dissolved $\mathrm{N}_{2} \mathrm{O}$ (a) and ion, parameters and $\delta^{15} \mathrm{~N}^{-\mathrm{NO}_{3}}{ }_{3}^{-}$

After sample for gas analysis was taken, water sample for ion, parameters and $\delta^{15} \mathrm{~N}^{-\mathrm{NO}_{3}}{ }^{-}$analysis were collected by a pipe sampler (Figure $2 \mathrm{~b}$ ). When the pipe is put into water, a plastic ball at the bottom of the pipe can go up due to floatage that let the water into the pipe. The ball go back to the bottom when the pipe out of water that seal the pipe. Then, water samples were taken from the piezometers separately. Samples were brought back to the laboratory and stored at $4{ }^{\circ} \mathrm{C}$ before laboratory analysis. DO, $\mathrm{pH}$, ORP, and temperature of groundwater were 
measured in situ with sensors (HIROBA). All water samples were filtered $(0.45 \mu \mathrm{m})$ before analysis for major ions by ion chromatography (Shimadzu CDD-6A and CDD-10Avp). $2 \mathrm{~L}$ water for each sample was collected for $\delta^{15} \mathrm{~N}^{-\mathrm{NO}_{3}}{ }^{-}$analysis in March 2012. $\mathrm{NO}_{3}{ }^{-}$was collected by passing the water through pre-filled, disposable, anion exchanging resin columns in the field and then was eluted by $3 \mathrm{M} \mathrm{HCl}$ from the column. The nitrate-bearing acid eluant was neutralized with $\mathrm{Ag}_{2} \mathrm{O}$, filtered to remove the $\mathrm{AgCl}$ precipitate, then freeze dried to obtain solid $\mathrm{AgNO}_{3}$, which was then combusted to $\mathrm{N}_{2}$ in sealed quartz tubes for analysis by Integra $\mathrm{CN}$ mass spectrometer (Pdz Europa LTD) at Chiba University, Japan (Yingjie Cao, Tang, Song, Liu, \& Zhang, 2012). All the samples were measured twice and the result showed the difference between the two measurements was less than $\pm 5 \%$. Then the mean of two measurements was used as the value of $\delta^{15} \mathrm{~N}^{-\mathrm{NO}_{3}}{ }^{-}$in this study.

\subsection{Statistical Analysis}

Variables were tested using student t-test and principal component analysis (PCA), with SPSS 8.0 for Windows (SPSS, 1997, IL, USA). T-test was used to determine if two sets of data are significantly different from each other. The PCA is a data transformation technique that attempts to reveal a simple understanding structure that is assumed to exist within a multivariate dataset (Davis, 1986).

\section{Results}

\subsection{Basic Parameters and Dissolved $\mathrm{N}_{2} \mathrm{O}$ in Upland Shallow Groundwater}

Samples were taken from W1 in July and November 2012, respectively. DO and ORP concentrations were higher in July (Table 1). pH values of groundwater were lower than 7 both in July and November. Groundwater temperature was little higher in July than that in November. $\mathrm{NO}_{3}{ }^{-}-\mathrm{N}$ and $\mathrm{N}_{2} \mathrm{O}-\mathrm{N}$ concentrations were both higher in July than that in November.

Table 1. Basic parameters and dissolved $\mathrm{N}_{2} \mathrm{O}$ of upland shallow groundwater in July and November 2012

\begin{tabular}{lllllll}
\hline & $\mathrm{N}_{2} \mathrm{O}-\mathrm{N}\left(\mu \mathrm{g} \mathrm{L}^{-1}\right)$ & $\mathrm{DO}\left(\mathrm{mg} \mathrm{L}^{-1}\right)$ & $\mathrm{ORP}(\mathrm{mv})$ & $\mathrm{NO}_{3}{ }^{-}-\mathrm{N}\left(\mathrm{mgL}^{-1}\right)$ & $\mathrm{T}\left({ }^{\circ} \mathrm{C}\right)$ & $\mathrm{pH}$ \\
\hline Jul & 14.73 & 9.29 & 325 & 34.74 & 18.3 & 6.94 \\
Nov & 8.11 & 5.70 & 295 & 17.30 & 16.9 & 6.05 \\
\hline
\end{tabular}

\subsection{Basic Parameters and Dissolved $\mathrm{N}_{2} \mathrm{O}$ in Wetland Shallow Groundwater}

Groundwater temperatures in the wetland ranged from 14.2 to $24.8{ }^{\circ} \mathrm{C}$ during the study period (Table 2). $\mathrm{pH}$ values of groundwater ranged from 6.53 to 7.97 , indicating that the groundwater was alkaline except S14 which $\mathrm{pH}$ was lower than 7 during the warm season. DO concentrations ranged from 0.07 to $11.50 \mathrm{mg} \mathrm{L}^{-1}$. It was lower than $4 \mathrm{mg} \mathrm{L}^{-1}$, and as low as $0.07 \mathrm{mg} \mathrm{L}^{-1}$ in June at R2. At S4 and S14, the DO concentrations were lower than 5 $\mathrm{mg} \mathrm{L}^{-1}$ in the warm season, but up to $11.5 \mathrm{mg} \mathrm{L}^{-1}$ in the cool season (S14-3 $\mathrm{m}$ in November). ORP values ranged from -244 to $303 \mathrm{mV}$. At $1 \mathrm{~m}$ and $2 \mathrm{~m}$ depth of R2, ORP values were below about $0 \mathrm{mV}$ in the warm season with the lowest value of $-189 \mathrm{mV}$. However, ORP was up to $175 \mathrm{mV}$ in March. At $3 \mathrm{~m}$ depth of R2, ORP was above $0 \mathrm{mV}$ except in September $(-244 \mathrm{mV})$. The $\mathrm{NO}_{3}^{-}-\mathrm{N}$ concentration changed from 0 to $114.0 \mathrm{mg} \mathrm{L}^{-1}$ in study sites. At $\mathrm{S} 4$ and $\mathrm{S} 14$, most $\mathrm{NO}_{3}{ }^{-}-\mathrm{N}$ concentrations are clearly above the standard of the drinking water $\left(10 \mathrm{mg} \mathrm{L}^{-1}\right)$ set by United States Environment Protection Agency (Figure 3), whereas $\mathrm{NO}_{3}^{-}-\mathrm{N}$ concentration was extremely low for detection at $\mathrm{R} 2 . \mathrm{NH}_{4}{ }^{+}$and $\mathrm{NO}_{2}^{-}$were also measured with other major ions, and found below the detectable limit. 
Table 2. $\mathrm{T}\left({ }^{\circ} \mathrm{C}\right) \mathrm{pH}$ DO $\left(\mathrm{mg} \mathrm{L}^{-1}\right)$, and ORP $(\mathrm{mV})$ of the groundwater at $\mathrm{S} 4, \mathrm{~S} 14$ and $\mathrm{R} 2 \mathrm{in} 1 \mathrm{~m}, 2 \mathrm{~m}$ and $3 \mathrm{~m}$ depth

\begin{tabular}{|c|c|c|c|c|c|c|c|c|c|c|c|c|}
\hline \multirow[t]{2}{*}{ Site } & \multicolumn{2}{|c|}{ May/11 } & \multicolumn{2}{|c|}{$\mathrm{Jul} / 11$} & \multicolumn{2}{|c|}{ Sep/11 } & \multicolumn{2}{|c|}{ Nov/11 } & \multicolumn{2}{|c|}{ Mar/12 } & \multicolumn{2}{|c|}{ Jun/12 } \\
\hline & $\mathrm{T}$ & $\mathrm{pH}$ & $\mathrm{T}$ & $\mathrm{pH}$ & $\mathrm{T}$ & $\mathrm{pH}$ & $\mathrm{T}$ & $\mathrm{pH}$ & $\mathrm{T}$ & $\mathrm{pH}$ & $\mathrm{T}$ & $\mathrm{pH}$ \\
\hline S4-1 & 14.7 & 7.70 & 19.7 & 6.99 & 24.8 & 7.56 & 14.7 & 7.48 & 15.4 & 7.38 & 19.4 & 7.15 \\
\hline S4-2 & 15.2 & 7.62 & 19.1 & 7.05 & 24.8 & 7.50 & 15.2 & 7.41 & 14.8 & 7.36 & 19.1 & 7.23 \\
\hline S4-2 & 14.9 & 7.42 & 19.9 & 7.18 & 18.4 & 7.53 & 14.9 & 7.40 & 14.5 & 7.54 & 18.5 & 7.52 \\
\hline R2-1 & 16.2 & 7.48 & 23.2 & 6.90 & 24.7 & 7.15 & 16.2 & 7.63 & 19 & 7.49 & 22.5 & 6.94 \\
\hline R2-2 & 16.4 & 7.72 & 21.0 & 7.17 & 21.4 & 7.47 & 16.4 & 7.59 & 15.3 & 7.59 & 20.3 & 7.07 \\
\hline R2-3 & 15.5 & 7.97 & 20.7 & 7.30 & 20.8 & 7.72 & 15.5 & 7.65 & 17.7 & 7.63 & 20.3 & 7.17 \\
\hline S14-1 & 15.4 & 7.84 & 20.5 & 6.68 & 20.9 & 7.17 & 15.4 & 6.90 & 17.2 & 7.66 & 19.5 & 6.87 \\
\hline S14-2 & 15.0 & 7.63 & 19.4 & 6.58 & 18.3 & 7.03 & 15.0 & 6.71 & 17.1 & 7.79 & 18.9 & 6.84 \\
\hline S14-3 & 14.2 & 7.41 & 20.1 & 6.53 & 20.4 & 6.84 & 14.2 & 6.61 & 15.4 & 7.66 & 18.2 & 6.95 \\
\hline \multirow[t]{2}{*}{ Site } & \multicolumn{2}{|c|}{ May/11 } & \multicolumn{2}{|c|}{$\mathrm{Jul} / 11$} & \multicolumn{2}{|c|}{$\mathrm{Sep} / 11$} & \multicolumn{2}{|c|}{ Nov/11 } & \multicolumn{2}{|c|}{ Mar/12 } & \multicolumn{2}{|c|}{ Jun/12 } \\
\hline & DO & ORP & DO & ORP & DO & ORP & DO & ORP & DO & ORP & DO & ORP \\
\hline S4-1 & 7.31 & 287 & 2.90 & 185 & 3.26 & 284 & 6.82 & 287 & 7.41 & 267 & 3.16 & 269 \\
\hline S4-2 & 7.05 & 278 & 2.03 & 178 & 3.06 & 303 & 6.00 & 278 & 5.74 & 258 & 4.00 & 269 \\
\hline S4-2 & 8.09 & 260 & 2.46 & 191 & 1.80 & 287 & 8.26 & 260 & 8.26 & 272 & 2.73 & 280 \\
\hline R2-1 & 3.23 & 18 & 0.21 & -77 & 0.14 & -26 & 3.20 & 18 & 2.8 & 128 & 1.84 & -27 \\
\hline $\mathrm{R} 2-2$ & 3.95 & -173 & 1.55 & -177 & 0.13 & -189 & 2.80 & -173 & 2.59 & 175 & 0.13 & -150 \\
\hline R2-3 & 1.41 & 232 & 2.19 & 50 & 0.68 & -244 & 3.78 & 232 & 2.65 & 146 & 0.07 & 151 \\
\hline S14-1 & 7.2 & 280 & 2.35 & 147 & 4.59 & 197 & 9.35 & 280 & 4.75 & 287 & 3.13 & 126 \\
\hline $\mathrm{S} 14-2$ & 7.2 & 311 & 1.53 & 169 & 2.10 & 230 & 11.00 & 311 & 7.18 & 279 & 3.70 & 168 \\
\hline S14-3 & 6.69 & 292 & 2.44 & 177 & 2.36 & 229 & 11.50 & 292 & 6.61 & 279 & 4.03 & 164 \\
\hline
\end{tabular}

Dissolved $\mathrm{N}_{2} \mathrm{O}$ concentrations ranged from 0.09 to $100.62 \mu \mathrm{g} \mathrm{L} \mathrm{L}^{-1}$ (Figure 3). At $\mathrm{S} 4$, dissolved $\mathrm{N}_{2} \mathrm{O}$ ranged from 6.13 to $79.96 \mu \mathrm{g} \mathrm{L}^{-1}$ with the highest concentrations in July and the lowest values in March. At S14, dissolved $\mathrm{N}_{2} \mathrm{O}$ ranged from 7.8 to $100.62 \mu \mathrm{g} \mathrm{L} \mathrm{L}^{-1}$ with the highest values in July and the lowest values in November. At R2, dissolved $\mathrm{N}_{2} \mathrm{O}$ ranged from 0.09 to $2.29 \mu \mathrm{g} \mathrm{L}^{-1}$ at $1 \mathrm{~m}$ in depth, and from 1.41 to $50.16 \mu \mathrm{g} \mathrm{L}^{-1}$ at $2 \mathrm{~m}$ and $3 \mathrm{~m}$ in depth.
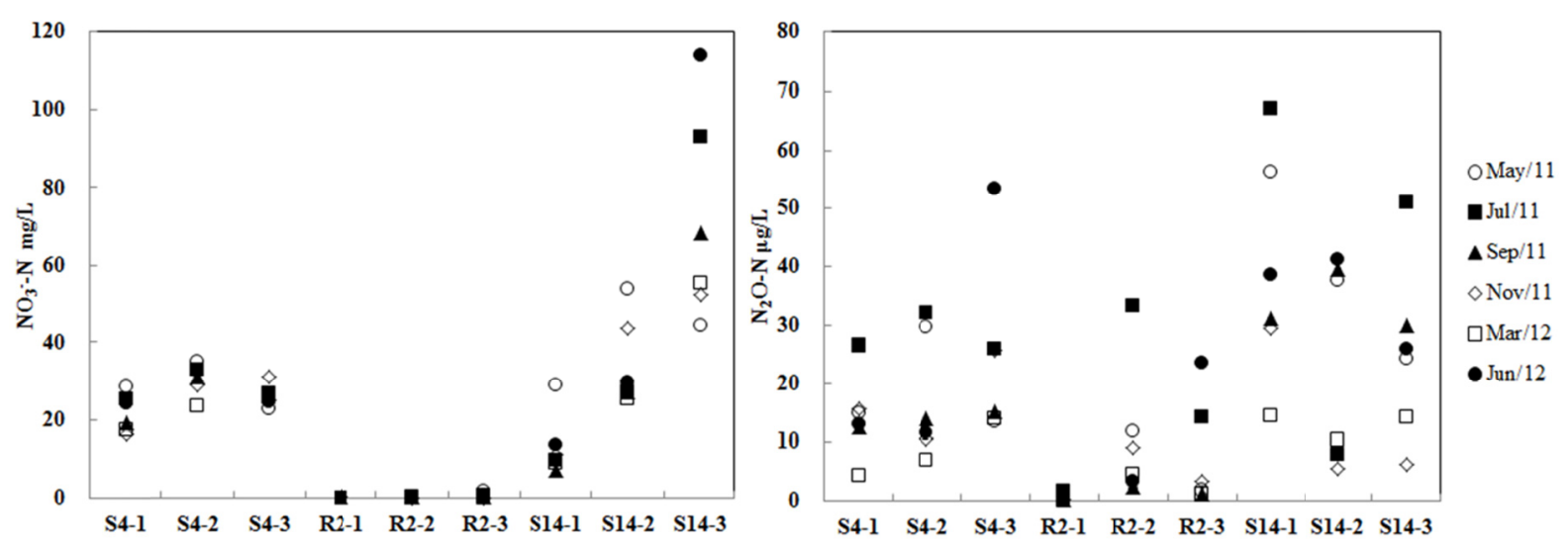

Figure 3. Variations of $\mathrm{NO}_{3}{ }^{-}-\mathrm{N}$ and $\mathrm{N}_{2} \mathrm{O}-\mathrm{Nat} \mathrm{S} 4, \mathrm{~S} 14$ and $\mathrm{R} 2$ in $1 \mathrm{~m}, 2 \mathrm{~m}$ and $3 \mathrm{~m}$ depth (Open cycles: the cool season; Closed cycles: the warm season) 


\subsection{Variations of $\delta^{15}{\mathrm{~N}-\mathrm{NO}_{3}}^{-}$in Shallow Groundwater}

$\delta^{15} \mathrm{~N}^{-\mathrm{NO}_{3}}{ }_{3}^{-}$in shallow groundwater of upland (W1) was 5.67\%o (Table 3). The $\delta^{15} \mathrm{~N}^{-\mathrm{NO}_{3}}{ }^{-}$in groundwater was $6.36 \%$ for $1 \mathrm{~m}$ and $8.27 \%$ for $2 \mathrm{~m}$ at $\mathrm{S} 4$, respectively. It was $8.7 \%$ for $1 \mathrm{~m}, 9.81 \%$ for $2 \mathrm{~m}$ and $7.67 \%$ or $3 \mathrm{~m}$ in depth at S14. The highest value was found in the groundwater $2 \mathrm{~m}$ at S14 and the lowest value at $\mathrm{W} 1$. Comparing with groundwater in the upland, $\delta^{15} \mathrm{~N}_{-} \mathrm{NO}_{3}{ }^{-}$was enriched from $0.69 \%$ to $4.14 \%$ in the wetland. However, it was undetectable at $\mathrm{R} 2$ because little nitrate was available.

Table 3. $\delta^{15} \mathrm{~N}^{-\mathrm{NO}_{3}}{ }_{3}^{-}$in groundwater of wetland and upland

\begin{tabular}{ccccccc}
\hline & W1 & S4-1m & S4-3m & S14-1 & S14-2m & S14-3m \\
\hline$\delta^{15}{\mathrm{~N}-\mathrm{NO}_{3}}^{-}$ & $5.67 \% 0$ & $6.36 \% 0$ & $8.27 \% 0$ & $8.7 \% 0$ & $9.81 \% 0$ & $7.67 \% 0$ \\
\hline
\end{tabular}

\subsection{Statistical Analysis}

PCA was used to assess the shallow groundwater parameters in the wetland. To maximize the variance of the two principal axes, the varimax normalized rotation was applied. The load factors have been polarized after rotation of component matrix (Table 4). PCA results show two components with eigenvalues larger than 1, which explain $69.74 \%$ of the total variance. The first component explains about $39.894 \%$ of the observed variance. DO, T and ORP are correlated with the first component, representing the redox condition in the groundwater. The second component explains about $29.845 \%$ of the observed variation and is correlated with $\mathrm{NO}_{3}{ }^{-}, \mathrm{N}_{2} \mathrm{O}$ and $\mathrm{pH}$ which representing the reactants and products associated with denitrification process.

Table 4. Loadings for two principal components of groundwater variables in wetland

\begin{tabular}{lll}
\hline Variable & $\begin{array}{l}\text { Component 1 } \\
\text { (Rotated) }\end{array}$ & $\begin{array}{l}\text { Component 2 } \\
\text { (Rotated) }\end{array}$ \\
\hline $\mathrm{N}_{2} \mathrm{O}-\mathrm{N}$ & 0.089 & 0.735 \\
$\mathrm{DO}$ & 0.898 & 0.063 \\
$\mathrm{~T}$ & -0.859 & 0.231 \\
$\mathrm{ORP}$ & 0.758 & 0.338 \\
$\mathrm{NO}_{3}{ }^{-}-\mathrm{N}$ & 0.426 & 0.720 \\
$\mathrm{pH}^{\text {Variance }}$ & 0.294 & -0.748 \\
explained,\% of total & 39.894 & 29.845 \\
\hline
\end{tabular}

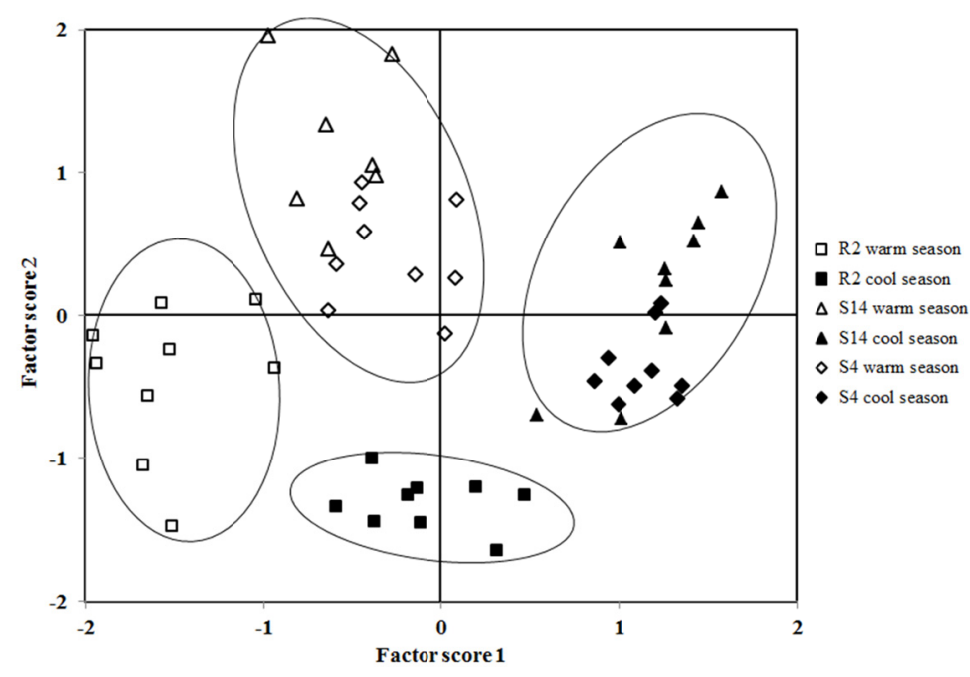

Figure 4. Bi-plot of the factor scores of the two principal components 
The scores represent the influence of the component on the groundwater (Figure 4). It is possible to group the samples according to the axes of component 1 and 2. As a result, the samples are classified into four groups to showing seasonal and spatial patterns. The samples of NS are plotted at the down-left of the diagram for the warm season and the down-middle for the cool season. On the other hand, the samples of ASW are plotted at the upper-left of the diagram for the warm season and the upper-right for the cool season.

As the result of the groups from PCA, mean value, standard deviation and a t-test was conducted to find the difference and statistically significant differences of the variables between the ASW and NS, warm season and cool season (Table 5). $\mathrm{NO}_{3}^{-}-\mathrm{N}$, DO, ORP and $\mathrm{N}_{2} \mathrm{O}-\mathrm{N}$ in groundwater were significantly higher at ASW than those at NS, whereas there was no significantly difference of temperature and $\mathrm{pH}$ between ASW and NS. For $\mathrm{N}_{2} \mathrm{O}-\mathrm{N}, \mathrm{NO}_{3}{ }^{-}-\mathrm{N}$ concentrations, and DO, variability was higher at ASW than those at NS on the basis of standard deviation. In contrast, variability of ORP was lower at ASW than it at NS. In addition, the mean $\mathrm{N}_{2} \mathrm{O}-\mathrm{N}$ concentration at ASW was high $\left(36.14 \mu \mathrm{g} \mathrm{L}^{-1}\right)$, which was about 60 times of that in the ambient air. $\mathrm{N}_{2} \mathrm{O}-\mathrm{N}$ concentration and temperature in groundwater were significant higher in warm season than those in cool season, and $\mathrm{DO}, \mathrm{ORP}$ and $\mathrm{pH}$ were significantly lower in warm season. There was no significant difference of $\mathrm{NO}_{3}{ }^{-} \mathrm{-N}$ concentrations between two seasons which seems to be the rule rather than the exception.

Table 5. Mean (m) and standard deviation (parentheses) of $\mathrm{N}_{2} \mathrm{O}, \mathrm{DO}, \mathrm{ORP}, \mathrm{NO}_{3}{ }^{-}$and $\mathrm{T}$ in shallow groundwater of ASW (n=36) and NS ( $\mathrm{n}=18)$

\begin{tabular}{lcccccc}
\hline Zone & $\mathrm{N}_{2} \mathrm{O}-\mathrm{N}\left(\mu \mathrm{g} \mathrm{L}^{-1}\right)$ & $\mathrm{DO}\left(\mathrm{mg} \mathrm{L}^{-1}\right)$ & $\mathrm{T}\left({ }^{\circ} \mathrm{C}\right)$ & $\mathrm{ORP}(\mathrm{mV})$ & $\mathrm{NO}_{3}{ }^{-}-\mathrm{N}\left(\mathrm{mg} \mathrm{L}^{-1}\right)$ & $\mathrm{pH}$ \\
\hline ASW & $36.14^{*}$ & $5.22^{*}$ & 17.60 n.s. & $237.00^{*}$ & $33.00^{*}$ & $7.24_{\text {n.s. }}$ \\
& $(23.79)$ & $(2.72)$ & $(2.84)$ & $(52.49)$ & $(22.08)$ & $(0.37)$ \\
$\mathrm{NS}$ & 9.27 & 1.85 & 19.10 & -5.00 & 0.01 & 7.42 \\
& $(13.87)$ & $(1.36)$ & $(2.98)$ & $(156.77)$ & $(0.36)$ & $(0.30)$ \\
\hline Warm & $34.19^{* *}$ & $2.17^{*}$ & $20.50^{*}$ & $117.19^{* *}$ & $23.5_{\text {n.s. }}$ & $7.11^{*}$ \\
& $(27.01)$ & $(1.30)$ & $(1.93)$ & $(162.66)$ & $(28.34)$ & $(0.30)$ \\
Cool & 20.19 & 6.03 & 15.6 & 209.67 & 20.6 & 7.49 \\
& $(19.75)$ & $(2.65)$ & $(1.12)$ & $(135.12)$ & $(18.60)$ & $(0.31)$ \\
\hline
\end{tabular}

n.s., Not significant $(\mathrm{p}>0.05)$

*The difference between mean values is highly significant $(\mathrm{p}<0.01)$

** The difference between mean values is significant $(\mathrm{p}<0.05)$

\section{Discussions}

\subsection{Source of Dissolved $\mathrm{N}_{2} \mathrm{O}$ of Shallow Groundwater}

In order to estimate the concentration of $\mathrm{N}_{2} \mathrm{O}$ in groundwater, it is important to identify its source. Fertilizer and manure ammonium-nitrogen applied in the orchard are oxidized to nitrate-nitrogen and nitrous oxide in unsaturated zone of the upland. Nitrate leaches to the groundwater from unsaturated zone in the upland. $\delta^{15} \mathrm{~N}_{-\mathrm{NO}_{3}}^{-}$value of W1 is coincided with range of $\delta^{15} \mathrm{~N}^{-\mathrm{NO}_{3}}{ }^{-}(+4.5 \%$ to $+8.5 \% 0)$ in the area effected by mineral fertilizer (Cao, Sun, Xing, \& Xu, 1991; Choi, Lee, \& Ro, 2003; Choi, Han, Lee, Lee, \& Yoon; Heaton, 1986; Singleton et al., 2007), indicating the dissolved $\mathrm{N}_{2} \mathrm{O}$ was produced via nitrification in the unsaturated zone of upland. DO concentrations were high at W1, indicating that denitrification could not occur. Nitrate and $\mathrm{N}_{2} \mathrm{O}$ transport from upland to wetland with groundwater consequently. $\mathrm{N}_{2} \mathrm{O}$ is difficult to denitrified to $\mathrm{N}_{2}$ because the groundwater in upland is often assumed to have low biological activity due to low $\mathrm{C}$ content (Groffman, Gold, \& Jacinthe, 1998). Geistlinger et al. (2010) found there will be a diffusive $\mathrm{N}_{2} \mathrm{O}$ flux from the deeper water to the capillary fringe. However the time scale of this process is very large i.e., for $10 \mathrm{~cm}$ travel distance, the $\mathrm{N}_{2} \mathrm{O}$ molecules need $\approx 230 \mathrm{~d}$. Thus, diffusive loss to upward is considered to have little effect on $\mathrm{N}_{2} \mathrm{O}$ concentration in the groundwater during transporting from upland to wetland.

At the wetland, denitrification can enrich ${ }^{15} \mathrm{~N}$ in the residual nitrate of groundwater (Cey, Rudolph, Aravena, \& Parkin, 1999; Lehmann, Reichert, Bernasconi, Barbieri, \& McKenzie, 2003). $\delta^{15} \mathrm{~N}_{-} \mathrm{NO}_{3}{ }^{-}$in the residual nitrate enriched from $2.8 \%$ to $78.32 \%$ when the concentration of $\mathrm{NO}_{3}^{-}-\mathrm{N}$ decreased from $35.68 \mathrm{mg} \mathrm{L}^{-1}$ to $0.45 \mathrm{mg} \mathrm{L}^{-1}$ 
in a sand aquifer (Böttcher, Strebel, Voerkelius, \& Schmidt, 1990), and from $6.4 \%$ to $24.8 \%$ when the $\mathrm{NO}_{3}{ }^{-} \mathrm{-N}$ concentration decreased from 13.3 to $5.6 \mathrm{mg} \mathrm{L}^{-1}$ in a riparian zone (Cey et al., 1999). In this study wetland, the $\delta^{15} \mathrm{~N}^{-\mathrm{NO}_{3}}{ }^{-}$enriched by $9.81 \%$ or even higher when the $\mathrm{NO}_{3}{ }^{-} \mathrm{N}$ was no longer detectable. Therefore, dissolved $\mathrm{N}_{2} \mathrm{O}$ in the shallow groundwater of wetland consists of two parts, one from denitrification within the wetland, and another from the upland where nitrification is dominant.

\subsection{Spatial and Seasonal Pattern of Dissolved $\mathrm{N}_{2} \mathrm{O}$ in Shallow Groundwater of the Wetland}

The previous section suggested that the source of dissolved $\mathrm{N}_{2} \mathrm{O}$ of groundwater in wetland comes from nitrification in upland and denitrification in wetland. In the study wetland, denitrification controls the behavior of dissolved $\mathrm{N}_{2} \mathrm{O}$. Because $\mathrm{N}_{2} \mathrm{O}$ is an intermediate product of denitrification that is producted when nitrate is reduced and is consumed by reduction to $\mathrm{N}_{2}$. Denitrification is considered to be related to many factors (DO, ORP, T, $\mathrm{pH}$ and $\mathrm{NO}_{3}{ }^{-}$). For example, the highest concentrations of $\mathrm{N}_{2} \mathrm{O}$ were found in the aerobic section of a limestone aquifer with the DO concentration below $4.00 \mathrm{mg} \mathrm{L}^{-1}$ and in a phreatic aerobic aquifers with the DO concentration below $3.15 \mathrm{mg} \mathrm{L}^{-1}$ (Deurer et al., 2008; Ronen, Magaritz, \& Almon, 1988). However, the optimal maximum DO concentration for nitrogen removal was determined to be around $2.0-2.5 \mathrm{mg} \mathrm{L}^{-1}$ in the laboratory experiments (Yoo et al., 1999). According the early study, Nelson and Knowles (1978) reported that the startup of denitrification can be inhibited while the oxygen level is as low as $0.13 \mathrm{mg} \mathrm{L}^{-1}$ in a dispersed-well sludge reactor. In the laboratory experiments, as the ORP drops below $0 \mathrm{mV}$, the nitrate begins to be converted to nitrite and nitrite accumulates continuously for ORP ranging from 0 to $-225 \mathrm{mV}$. From -225 to $-400 \mathrm{mV}$, the accumulated nitrite is converted to $\mathrm{N}_{2}$. As the ORP below $-400 \mathrm{mV}$, the nitrate is firstly converted first to nitrite then the nitrite is converted immediately to $\mathrm{N}_{2}$ without accumulation (Lee et al., 2000). It also reported that ORP below about 200 to $300 \mathrm{mV}$ were found to be conducive to denitrification, and the maximum $\mathrm{N}_{2} \mathrm{O}$ were found at a ORP value of $0 \mathrm{mV}$ (Kralova, Masscheleyn, Lindau, \& Patrick Jr, 1992). Therefore, the optimum value of DO and ORP for $\mathrm{N}_{2} \mathrm{O}$ accumulation is not consistent with the value of the optimum for denitrification due to the $\mathrm{N}_{2} \mathrm{O}$ is an intermediate product. For nitrate, DeSimone and Howes (1998) studied that kinetics of denitrification at nitrate concentrations $>1 \mathrm{mg}-\mathrm{N} \mathrm{L}^{-1}$ is zero order and even small amount of nitrate (lower than $2 \mathrm{mg}-\mathrm{N} \mathrm{kg}^{-1}$ ) leached was sufficient to create a large amount of $\mathrm{N}_{2} \mathrm{O}$ in groundwater (Müller, Stevens, Laughlin, \& Jäger, 2004). Many studies suggested that high concentration of $\mathrm{NO}_{3}{ }^{-} \mathrm{N}$ inhibits the $\mathrm{N}_{2} \mathrm{O}$ reductase yielding the higher concentration of $\mathrm{N}_{2} \mathrm{O}$ (Blackmer \& Bremner, 1978; Deurer et al., 2008; Heisterkamp, Schramm, de Beer, \& Stief, 2012). At ASW, the DO $\left(\mathrm{m}=5.22 \mathrm{mg} \mathrm{L}^{-1}\right)$ and $\mathrm{ORP}(\mathrm{m}=237 \mathrm{mV})$ values were both higher than the optimum values respectively, as well as high concentrations of $\mathrm{NO}_{3}{ }^{-}-\mathrm{N}$ which were conducive to $\mathrm{N}_{2} \mathrm{O}$ accumulation $(\mathrm{m}=$ $\left.36.14 \mu \mathrm{g} \mathrm{L}^{-1}\right)$ (Table 5). However, the mean value of DO concentrations $\left(2.02 \mathrm{mg} \mathrm{L}^{-1}\right)$ and ORP were much lower $(-5 \mathrm{mV})$ at NS. Additionally, $\mathrm{NO}_{3}{ }^{-} \mathrm{-N}$ is low or undetectable throughout the study. Under these conditions, the $\mathrm{N}_{2} \mathrm{O}$ is used as an electron acceptor instead of nitrate in denitrification process(Ishii, Ohno, Tsuboi, Otsuka, \& Senoo, 2011), resulting in the lower concentration $\left(\mathrm{m}=13.87 \mu \mathrm{g} \mathrm{L}^{-1}\right)$. Therefore, ASW and NS can be considered as in the stage 2 and stage 3, respectively. In addition, the average flux of $\mathrm{N}_{2} \mathrm{O}$ was found to be higher at ASW than it at NS (Li, Tang, Han, Cao, \& Zhang, 2013) which is consistent with the trend of dissolved $\mathrm{N}_{2} \mathrm{O}$.

Seasonal changes of dissolved $\mathrm{N}_{2} \mathrm{O}$ are most associated with $\mathrm{NO}_{3}{ }^{-}$concentration and water temperature (Bouwman, Boumans, \& Batjes, 2002; Hinshaw \& Dahlgren, 2013; Velthof, Oenema, Postma, \& Van Beusichem, 1996). The T-test indicates that the concentrations of $\mathrm{NO}_{3}^{-}-\mathrm{N}$ had no significant difference between the two seasons, which suggests $\mathrm{NO}_{3}{ }^{-} \mathrm{N}$ is not the limited factor for denitrification rate in study wetland (Table 5). Temperature affected the dissolved $\mathrm{N}_{2} \mathrm{O}$ directly by controlling the denitrification rate (Nowicki, 1994; Pfenning \& McMahon, 1997; Saunders \& Kalff, 2001). The threshold temperature for controlling the rate of denitrification was $20^{\circ} \mathrm{C}$ (Halling-Sørensen \& Jorgensen, 1993) or even below $17{ }^{\circ} \mathrm{C}$ (McCutchan \& Lewis, 2008; Nowicki, 1994). A study in coarse sandy soils found that the denitrification activity was low at $10^{\circ} \mathrm{C}$ and completely inhibited at 2 and $5{ }^{\circ} \mathrm{C}$ because lower temperature may regulate metabolic rates for denitrifying bacteria (Vinther \& Søeberg, 1991). Temperature also influences the solubility of oxygen, the rates of aerobic respiration of bacteria and the ORP change in groundwater, all of which in turn limit dissolved $\mathrm{N}_{2} \mathrm{O}$ indirectly. For example, the oxygen solubility is $14.60 \mathrm{mg} \mathrm{L}^{-1}$ at $0{ }^{\circ} \mathrm{C}$, about double at $30^{\circ} \mathrm{C}\left(7.54 \mathrm{mg} \mathrm{L}^{-1}\right)$ (Weiss, 1970). Oxygen consumption by aerobic respiration increases when the temperature increases (Thamdrup, Hansen, \& Jørgensen, 1998). When the temperature increased from $15^{\circ} \mathrm{C}$ to $25^{\circ} \mathrm{C}$, the average ORP decreased from +40 $\mathrm{mV}$ to $-60 \mathrm{mV}$ (Zhu, Ndegwa, \& Luo, 2002). In warm season, denitrification rate supposed not to be inhibited by temperature $\left(\mathrm{m}=20.5^{\circ} \mathrm{C}\right)$. The lower DO and ORP of groundwater could be assumed as a response to the higher temperature in the warm season. The characteristics of these factors resulted in the higher $\mathrm{N}_{2} \mathrm{O}$ concentration in the warm season $\left(\mathrm{m}=34.19 \mu \mathrm{g} \mathrm{L}^{-1}\right)$ than it in cool season $\left(20.19 \mu \mathrm{g} \mathrm{L}^{-1}\right)$. In addition, the decrease of $\mathrm{pH}$ was 
interpreted as a sign of intense denitrification (Ilies \& Mavinic, 2001). Mean value of $\mathrm{pH}$ is lower in the warm season $(\mathrm{m}=7.11)$ than it in the cool season $(\mathrm{m}=7.49)$, which also can explain the higher dissolved $\mathrm{N}_{2} \mathrm{O}$ concentrations in the warm season. The seasonal change of dissolved $\mathrm{N}_{2} \mathrm{O}$ coincides with $\mathrm{N}_{2} \mathrm{O}$ flux measured in the study wetland. In fact, the average monthly $\mathrm{N}_{2} \mathrm{O}$ flux ranged from 0.019 to $0.286 \mathrm{mg} \mathrm{N} \mathrm{m}^{-2} \mathrm{~h}^{-1}$ with the highest value in the warm season and the lowest flux appeared in the cool season (Li et al., 2013).

\section{Conclusions}

$\mathrm{N}_{2} \mathrm{O}$ concentrations, denitrification related factors $\left(\mathrm{NO}_{3}{ }^{-}, \mathrm{DO}, \mathrm{ORP}, \mathrm{pH}\right.$ and $\left.\mathrm{T}\right)$ and $\delta^{15} \mathrm{~N}^{-\mathrm{NO}_{3}}{ }^{-}$values were investigated in a typical headwater wetland and watershed. The main findings and conclusions are as follows:

Spatially, $\mathrm{NO}_{3}^{-}$, DO and ORP are main factors to control the dissolved $\mathrm{N}_{2} \mathrm{O}$ in groundwater of study area. DO, ORP and $\mathrm{NO}_{3}{ }^{-}$decreased continuously from upland to the wetland. Along the groundwater flow, the dissolved $\mathrm{N}_{2} \mathrm{O}$ was produced through nitrification at the upland and denitrification in the wetland, which is supported by the variations of $\delta^{15} \mathrm{~N}_{-} \mathrm{NO}_{3}{ }^{-}$in the shallow groundwater. The mean value of dissolved $\mathrm{N}_{2} \mathrm{O}-\mathrm{N}$ increased from $11.42 \mu \mathrm{g} \mathrm{L}^{-1}$ at upland to $36.14 \mu \mathrm{g} \mathrm{L}^{-1}$ at the ASW and then decreased to $9.27 \mu \mathrm{g} \mathrm{L}^{-1}$ at NS. The dissolved $\mathrm{N}_{2} \mathrm{O}$ in the ASW zone is expected to be composed of two parts. One is transported from the upland and the other is produced from denitrification in the wetland. As a result, the dissolved $\mathrm{N}_{2} \mathrm{O}$ in the groundwater can be classified into the stage 1 for the upland, the stage 2 for ASW and the stage 3 for NS in the study area. Seasonally, the $\mathrm{N}_{2} \mathrm{O}$ concentration was higher in the warm season $\left(\mathrm{m}=34.19 \mu \mathrm{g} \mathrm{L}^{-1}\right)$ and lower in the cool season $\left(\mathrm{m}=20.19 \mu \mathrm{g} \mathrm{L}^{-1}\right)$. Temperature and $\mathrm{pH}$ are main factors to control the dissolved $\mathrm{N}_{2} \mathrm{O}$ in groundwater of study area. Higher temperature results in higher denitrification rate by elevating metabolic rates for denitrifying bacteria directly, and creating the lower DO and ORP environment that affects the $\mathrm{N}_{2} \mathrm{O}$ concentration indirectly in the warm season. In addition, lower $\mathrm{pH}$ in the warm season also may explain the higher dissolved $\mathrm{N}_{2} \mathrm{O}$ concentrations because the decrease of $\mathrm{pH}$ is interpreted as a sign of intense denitrification.

This study put forward an understanding of spatial distributions of dissolved $\mathrm{N}_{2} \mathrm{O}$ from upland (agricultural area) which related the materials transformation to groundwater flow system. Temperature is considered as the main driver to seasonal change of dissolved $\mathrm{N}_{2} \mathrm{O}$ in wetland groundwater.

\section{Acknowledgements}

We would like to thank the wetland park of Ichikawa city and the farmers in the pear orchard for the assistance of water sampling.

\section{References}

Agriculture and Forestry Research Center of Chiba Prefecture. (2003). Soil improvement of pear orchards. Retrieved from http://www.pref.chiba.lg.jp/ninaite/fukyuushidou/kenkyuu-h15/documents/15chosa5.pdf

Bastviken, D., Olsson, M., \& Tranvik, L. (2003). Simultaneous measurements of organic carbon mineralization and bacterial production in oxic and anoxic lake sediments. Microbial ecology, 46(1), 73-82. http://dx.doi.org/10.1007/s00248-002-1061-9

Blackmer, A., \& Bremner, J. (1978). Inhibitory effect of nitrate on reduction of $\mathrm{N}_{2} \mathrm{O}$ to $\mathrm{N}_{2}$ by soil microorganisms. Soil Biology and Biochemistry, 10(3), 187-191. http://dx.doi.org/10.1016/0038-0717(78)90095-0

Böttcher, J., Strebel, O., Voerkelius, S., \& Schmidt, H.-L. (1990). Using isotope fractionation of nitrate-nitrogen and nitrate-oxygen for evaluation of microbial denitrification in a sandy aquifer. Journal of Hydrology, 114(3), 413-424. http://dx.doi.org/10.1016/0022-1694 (90)90068-9

Bouwman, A., Boumans, L., \& Batjes, N. (2002). Modeling global annual $\mathrm{N}_{2} \mathrm{O}$ and $\mathrm{NO}$ emissions from fertilized fields. Global Biogeochemical Cycles, 16(4), 28-21-28-29. http://dx.doi.org/10.1029/2001GB001812

Burgin, A. J., \& Hamilton, S. K. (2007). Have we overemphasized the role of denitrification in aquatic ecosystems? A review of nitrate removal pathways. Frontiers in Ecology and the Environment, 5(2), 89-96. http://dx.doi.org/10.1890/1540-9295(2007)5[89:HWOTRO]2.0.CO;2

Butler, J. H., Elkins, J. W., Thompson, T. M., \& Egan, K. B. (1989). Tropospheric and dissolved $\mathrm{N}_{2} \mathrm{O}$ of the west Pacific and east Indian Oceans during the El Nino Southern Oscillation event of 1987. Journal of Geophysical Research, 94(D12), 14865-14814,14877. http://dx.doi.org/10.1029/JD094iD12p14865

Cao, Y., Sun, G., Xing, G., \& Xu, H. (1991). Natural abundance of $15 \mathrm{~N}$ in main N-containing chemical fertilizers of China. Pedosphere, 1(4), 377-382. Retrieved from http://pedosphere.issas.ac.cn/trqcn/ch/reader/view_abstract.aspx?file_no=19910410\&flag=1 
Cao, Y., Tang, C., Song, X., Liu, C., \& Zhang, Y. (2012). Characteristics of nitrate in major rivers and aquifers of the Sanjiang Plain, China. Journal of Environmental Monitoring, 14(10), 2624-2633. http://dx.doi.org/10.1039/C2EM30032J

Cey, E. E., Rudolph, D. L., Aravena, R., \& Parkin, G. (1999). Role of the riparian zone in controlling the distribution and fate of agricultural nitrogen near a small stream in southern Ontario. Journal of Contaminant Hydrology, 37(1), 45-67. http://dx.doi.org/10.1016/S0169-7722 (98)00162-4

Choi, W.-J., Han, G.-H., Lee, S.-M., Lee, G.-T., Yoon, K.-S., Choi, S.-M., \& Ro, H.-M. (2007). Impact of land-use types on nitrate concentration and $\delta^{15} \mathrm{~N}$ in unconfined groundwater in rural areas of Korea. Agriculture, Ecosystems and Environment, 120, 259-268. http://dx.doi.org/10.1016/j.agee.2006.10.002

Choi, W.-J., Lee, S. M., \& Ro, H. M. (2003). Evaluation of contamination sources of groundwater $\mathrm{NO}_{3}{ }^{-}$using nitrogen isotope data: A review. Geosciences Journal, 7(1), 81-87. http://dx.doi.org/10.1016/S0038-0717(03)00199-8

Davis, J. C. (1986). Statistical and data analysis in geology (2nd ed.). New York, John Wiley and Sons.

DeSimone, L. A., \& Howes, B. L. (1998). Nitrogen transport and transformations in a shallow aquifer receiving wastewater discharge: A mass balance approach. Water Resources Research, 34(2), 271-285. http://dx.doi.org/10.1029/97WR03040

Deurer, M., Von Der Heide, C., Böttcher, J., Duijnisveld, W., Weymann, D., \& Well, R. (2008). The dynamics of $\mathrm{N}_{2} \mathrm{O}$ near the groundwater table and the transfer of $\mathrm{N}_{2} \mathrm{O}$ into the unsaturated zone: A case study from a sandy aquifer in Germany. Catena, 72(3), 362-373. http://dx.doi.org/10.1016/j.catena.2007.07.013

Dhondt, K., Boeckx, P., Hofman, G., \& Van Cleemput, O. (2004). Temporal and spatial patterns of denitrification enzyme activity and nitrous oxide fluxes in three adjacent vegetated riparian buffer zones. Biology and Fertility of Soils, 40(4), 243-251. http://dx.doi.org/10.1007/s00374-004-0773-z

Dividson, E., Stark, J. M., \& Firestone, M. (1990). Microbial production and consumpution of nitrate in an annual grassland. Ecology, 1968-1975. http://dx.doi.org/10.2307/1937605

Ferrón, S., Ortega, T., \& Forja, J. M. (2010). Nitrous oxide distribution in the north-eastern shelf of the Gulf of Cádiz (SW Iberian Peninsula). Marine Chemistry, 119(1), 22-32. http://dx.doi.org/10.1016/j.marchem.2009.12.003

García-García, V., Gómez, R., Vidal-Abarca, M., \& Suárez, M. (2009). Nitrogen retention in natural Mediterranean wetland-streams affected by agricultural runoff. Hydrology and Earth System Sciences, 13(12), 2359-2371. http://dx.doi.org/10.5194/hess-13-2359-2009

Geistlinger, H., Jia, R., Eisermann, D., \& Florian Stange, C. (2010). Spatial and temporal variability of dissolved nitrous oxide in near - surface groundwater and bubble - mediated mass transfer to the unsaturated zone. Journal of Plant Nutrition and Soil Science, 173(4), 601-609. http://dx.doi.org/10.1002/jpln.200800278

Groffman, P. M., Gold, A. J., \& Addy, K. (2000). Nitrous oxide production in riparian zones and its importance to national emission inventories. Chemosphere-Global change science, 2(3), 291-299. http://dx.doi.org/10.1016/S1465-9972(00)00018-0

Groffman, P. M., Gold, A. J., \& Jacinthe, P.-A. (1998). Nitrous oxide production in riparian zones and $\begin{array}{llll}\text { groundwater. } & \text { Nutrient } & \text { Cycling }\end{array}$ http://dx.doi.org/179-186.10.1023/A:1009719923861

Groffman, P. M., Gold, A. J., \& Simmons, R. C. (1992). Nitrate dynamics in riparian forests: microbial studies. Journal of Environmental Quality, http://dx.doi.org/10.2134/jeq1992.00472425002100040022x

Halling-Sørensen, B., \& Jorgensen, S. E. (1993). The removal of nitrogen compounds from wastewater. The Netherlands, Elsevier, Amsterdam.

Heaton, T. (1986). Isotopic studies of nitrogen pollution in the hydrosphere and atmosphere: a review. Chemical Geology, 59(1), 87-102. Retrieved from http://media.wix.com/ugd/adde68_965ca6eb9c72111a2c7fb3eee5f9a16f.pdf

Heincke, M., \& Kaupenjohann, M. (1999). Effects of soil solution on the dynamics of $\mathrm{N}_{2} \mathrm{O}$ emissions: a review. Nutrient Cycling in Agroecosystems, 55(2), 133-157. http://dx.doi.org/10.1023/A:1009842011599 
Heisterkamp, I. M., Schramm, A., de Beer, D., \& Stief, P. (2012). Incomplete denitrification in the gut of the aquacultured shrimp Litopenaeus vannamei as source of nitrous oxide. Microbial nitrous oxide production and nitrogen cycling associated with aquatic invertebrates, 135 . Retrieved from http://elib.suub.uni-bremen.de/edocs/00102789-1.pdf\#page=135

Hinshaw, S. E., \& Dahlgren, R. A. (2013). Dissolved Nitrous Oxide Concentrations and Fluxes from the Eutrophic San Joaquin River, California. Environmental science \& technology, 47(3), 1313-1322. http://dx.doi.org/10.1021/es301373h

Ilies, P., \& Mavinic, D. (2001). The effect of decreased ambient temperature on the biological nitrification and denitrification of a high ammonia landfill leachate. Water Research, 35(8), 2065-2072. http://dx.doi.org/10.1016/S0043-1354(00)00477-2

Ishii, S., Ohno, H., Tsuboi, M., Otsuka, S., \& Senoo, K. (2011). Identification and isolation of active $\mathrm{N}_{2} \mathrm{O}$ reducers in rice paddy soil. The ISME journal, 5(12), 1936-1945. http://dx.doi.org/10.1038/ismej.2011.69

Kim, D.-G., Isenhart, T., Parkin, T., Schultz, R., \& Loynachan, T. (2009). Nitrate and dissolved nitrous oxide in groundwater within cropped fields and riparian buffers. Biogeosciences Discussions, 6(1), 651-685. http://dx.doi.org/10.5194/bgd-6-651-2009

Kralova, M., Masscheleyn, P., Lindau, C., \& Patrick Jr, W. (1992). Production of dinitrogen and nitrous oxide in soil suspensions as affected by redox potential. Water, Air, and Soil Pollution, 61(1-2), 37-45. http://dx.doi.org/10.1007/BF00478364

Lee, P. G., Lea, R., Dohmann, E., Prebilsky, W., Turk, P., Ying, H., \& Whitson, J. (2000). Denitrification in aquaculture systems: an example of a fuzzy logic control problem. Aquacultural Engineering, 23(1), 37-59. http://dx.doi.org/10.1016/S0144-8609(00)00046-7

Lehmann, M. F., Reichert, P., Bernasconi, S. M., Barbieri, A., \& McKenzie, J. A. (2003). Modelling nitrogen and oxygen isotope fractionation during denitrification in a lacustrine redox-transition zone. Geochimica et Cosmochimica Acta, 67(14), 2529-2542. http://dx.doi.org/10.1016/S0016-7037(03)00085-1

Li, X., Tang, C., Han, Z., Cao, Y., \& Zhang, C. (2013). Relation between nitrous oxide production in wetland and groundwater: a case study in the headwater wetland. Paddy and Water Environment, 11(1-4), 521-529. http://dx.doi.org/10.1007/s10333-012-0345-z

Mathieu, O., Lévêque, J., Hénault, C., Milloux, M.-J., Bizouard, F., \& Andreux, F. (2006). Emissions and spatial variability of $\mathrm{N}_{2} \mathrm{O}, \mathrm{N}_{2} \mathrm{O}$ and nitrous oxide mole fraction at the field scale, revealed with ${ }^{15} \mathrm{~N}$ isotopic techniques. Soil Biology and Biochemistry, 38(5), 941-951. http://dx.doi.org/10.1016/j.soilbio.2005.08.010

McCutchan, J., \& Lewis, W. (2008). Spatial and temporal patterns of denitrification in an effluent-dominated plains river. Internationale Vereinigung fur Theoretische und Angewandte Limnologie Verhandlungen, 30(2), 323. Retrieved from http://cires.colorado.edu/limnology/pubs/pdfs/Pub192.pdf

Mühlherr, I. H., \& Hiscock, K. M. (1998). Nitrous oxide production and consumption in British limestone aquifers. Journal of Hydrology, 211(1), 126-139. http://dx.doi.org/10.1016/S0022-1694 (98)00224-8

Müller, C., Stevens, R., Laughlin, R., \& Jäger, H.-J. (2004). Microbial processes and the site of $\mathrm{N}_{2} \mathrm{O}$ production in a temperate grassland soil. Soil Biology and Biochemistry, 36(3), 453-461. http://dx.doi.org/10.1016/j.soilbio.2003.08.027

Nelson, L., \& Knowles, R. (1978). Effect of oxygen and nitrate on nitrogen fixation and denitrification by Azospirillum brasilense grown in continuous culture. Canadian journal of microbiology, 24(11), 1395-1403. http://dx.doi.org/10.1139/m78-223

Nowicki, B. L. (1994). The effect of temperature, oxygen, salinity, and nutrient enrichment on estuarine denitrification rates measured with a modified nitrogen gas flux technique. Estuarine, Coastal and Shelf Science, 38(2), 137-156. http://dx.doi.org/10.1006/ecss.1994.1009

Pfenning, K., \& McMahon, P. (1997). Effect of nitrate, organic carbon, and temperature on potential denitrification rates in nitrate-rich riverbed sediments. Journal of Hydrology, 187(3), 283-295. http://dx.doi.org/10.1016/S0022-1694 (96)03052-1

Rice, C. W., \& Rogers, K. L. (1993). Denitrification in subsurface environments: potential source for atmospheric nitrous oxide. Agricultural ecosystem effects on trace gases and global climate change (agriculturaleco), 121-132. http://dx.doi.org/10.2134/asaspecpub55.c 
Ronen, D., Magaritz, M., \& Almon, E. (1988). Contaminated aquifers are a forgotten component of the global $\mathrm{N}_{2} \mathrm{O}$ budget. Nature, 335, 57-59 http://dx.doi.org/10.1038/335057a0

Ross, S. (1995). Overview of the hydrochemistry and solute processes in British wetlands. Hydrology and hydrochemistry of British wetlands, 135, 181. Chichester, UK, Wiley.

Sabater, S., Butturini, A., Clement, J.-C., Burt, T., Dowrick, D., Hefting, M., \& Rzepecki, M. (2003). Nitrogen removal by riparian buffers along a European climatic gradient: patterns and factors of variation. Ecosystems, 6(1), 0020-0030. http://dx.doi.org/10.1007/s10021-002-0183-8

Saunders, D., \& Kalff, J. (2001). Nitrogen retention in wetlands, lakes and rivers. Hydrobiologia, 443(1-3), 205-212. http://dx.doi.org/10.1016/S0022-1694 (96)03052-1

Singleton, M., Esser, B., Moran, J., Hudson, G., McNab, W., \& Harter, T. (2007). Saturated zone denitrification: Potential for natural attenuation of nitrate contamination in shallow groundwater under dairy operations. Environmental science \& technology, 41(3), 759-765. http://dx.doi.org/10.1021/es061253g

Spalding, R. F., \& Parrott, J. D. (1994). Shallow groundwater denitrification. Science of the total environment, 141(1), 17-25. http://dx.doi.org/10.1016/0048-9697 (94)90014-0

Thamdrup, B., Hansen, J. W., \& Jørgensen, B. B. (1998). Temperature dependence of aerobic respiration in a $\begin{array}{lllll}\text { coastal sediment. } & \text { FEMS }\end{array}$ http://dx.doi.org/10.1111/j.1574-6941.1998.tb00472.x

Ueda, S., Ogura, N., \& Yoshinari, T. (1993). Accumulation of nitrous oxide in aerobic groundwaters. Water Research, 27(12), 1787-1792. http://dx.doi.org/10.1016/0043-1354(93)90118-2

Velthof, G., Oenema, O., Postma, R., \& Van Beusichem, M. (1996). Effects of type and amount of applied nitrogen fertilizer on nitrous oxide fluxes from intensively managed grassland. Nutrient Cycling in Agroecosystems, 46(3), 257-267. http://dx.doi.org/10.1007/BF00420561

Verhoeven, J. T., Arheimer, B., Yin, C., \& Hefting, M. M. (2006). Regional and global concerns over wetlands and water quality. Trends in ecology \& evolution, 21(2), 96-103. http://dx.doi.org/10.1016/j.tree.2005.11.015

Vinther, A., \& Søeberg, H. (1991). Mathematical model describing dispersion in free solution capillary electrophoresis under stacking conditions. Journal of Chromatography A, 559(1), 3-26. http://dx.doi.org/10.1016/0021-9673 (91)80055-L

Wang, S., Liu, C., Yeager, K. M., Wan, G., Li, J., Tao, F., \& Fan, C. (2009). The spatial distribution and emission of nitrous oxide $\left(\mathrm{N}_{2} \mathrm{O}\right)$ in a large eutrophic lake in eastern China: Anthropogenic effects. Science of the Total Environment, 407(10), 3330-3337. http://dx.doi.org/10.1016/j.scitotenv.2008.10.037

Weiss, R. (1970). The solubility of nitrogen, oxygen and argon in water and seawater. Paper presented at the Deep Sea Research and Oceanographic Abstracts. http://dx.doi.org/10.1016/0011-7471 (70)90037-9

Whitmire, S. L., \& Hamilton, S. K. (2005). Rapid removal of nitrate and sulfate in freshwater wetland sediments. Journal of Environmental Quality, 34(6), 2062-2071. http://dx.doi.org/10.2134/jeq2004.0483

Yoo, H., Ahn, K.-H., Lee, H. J., Lee, K. H., Kwak, Y. J., \& Song, K. G. (1999). Nitrogen removal from synthetic wastewater by simultaneous nitrification and denitrification (SND) via nitrite in an intermittently-aerated reactor. Water Research, 33(1), 145-154. http://dx.doi.org/10.1016/S0043-1354(98)00159-6

Zhang, G. L., Zhang, J., Liu, S. M., Ren, J. L., \& Zhao, Y. C. (2010). Nitrous oxide in the Changjiang (Yangtze River) Estuary and its adjacent marine area: Riverine input, sediment release and atmospheric fluxes. Biogeosciences, 7(11), 3505-3516. http://dx.doi.org/10.5194/bg-7-3505-2010

Zhu, J., Ndegwa, P. M., \& Luo, A. (2002). Bacterial responses to temperature during aeration of pig slurry. Journal of Environmental Science and Health, Part B, 37(3), 265-275. http://dx.doi.org/10.1081/PFC-120003104

\section{Copyrights}

Copyright for this article is retained by the author(s), with first publication rights granted to the journal.

This is an open-access article distributed under the terms and conditions of the Creative Commons Attribution license (http://creativecommons.org/licenses/by/3.0/). 